Огляди літератури, оригінальні дослідження, погляд на проблему, ювілеї

УДК 616.718.49/.728.3-018.3-007.248-08-039.76-053.89

DOI 10.11603/1811-2471.2018.v0.i4.9735

\title{
ПАТОБІОМЕХАНІЧНІ ПОРУШЕННЯ ТА МЕТОДИ КОРЕКЦІї ПРИ ПЕРВИННОМУ ГОНАРТРОЗІ У ПАЦІЄНТІВ ПОХИЛОГО ВІКУ
}

\author{
๑Т. Г. Бакалюк, І. Р. Мисула, Г. О. Стельмах, Ю. В. Завіднюк, Х. Я. Максів, Н. Б. Жеворонко \\ ДВНЗ «Тернопільський державний медичний університет імені І. Я. Горбачевського МОз України»
}

РЕзЮМЕ. В осіб похилого та старечого віку проблема остеоартрозу (ОА) набуває особливого значення у зв'язку з супутніми захворюваннями та інволютивними змінами в організмі. Патологія колінних суглобів спричиняє зміни функціонування всього опорно-рухового апарату, в першу чергу хребта. Підбір для хворих на ОА реабілітаційних комплексних програм, які дозволять відновити статико-динамічні властивості кістково-м'язової системи, і будуть мати одночасно протизапальну, знеболювальну та антиспазмолітичну дію, залишається актуальним завданням. Все це спонукає до пошуку шляхів корекції патобіомеханічних порушень при проведенні реабілітації хворих на ОА колінних суглобів в похилому віці.

Мета роботи - патогенетичне обґрунтування застосування реабілітаційного комплексу із включенням методик для корекції патобіомеханічних порушень у хворих на первинний гонартроз в похилому віці на амбулаторному етапі реабілітації.

Матеріали і методи. У дослідженні брали участь 42 хворих на первинний гонартроз із неспецифічним больовим синдромом у поперековому відділі хребта, які знаходились на амбулаторному етапі реабілітації. Середній вік становив $(65,13 \pm 0,31)$ р., тривалість захворювання - $(9,24 \pm 0,42)$ р. Пацієнти були поділені на 2 групи, реабілітаційні комплекси відрізнялись за методиками застосування об'ємного пневмопресингу.

Результати. Встановлено достовірне $(p<0,05)$ зменшення больового синдрому як у суглобі, так і в поперековому відділі хребта, покращення функціональної активності, тонусу м'язів та фізичної працездатності при застосуванні запропонованого реабілітаційного комплексу із корекцією патобіомеханічних порушень.

Висновки. На основі отриманих результатів запропоновано диференційований підхід до призначення реабілітаційних заходів у хворих на первинний гонартроз залежно від патобіомеханічних порушень. За допомогою комбінованої методики застосування об'ємного пневмопресингу локально на колінні суглоби та на м'язи спини усуваються зміни в м'язовому апараті колінних суглобів та хребта.

КЛючОВІ СлОВА: м'язова дисфункція; об'ємний пневмопресинг; остеоартроз; патобіомеханічні порушення; реабілітація.

Вступ. Сучасна демографічна ситуація в країні і дані статистичних прогнозів свідчать про збільшення кількості людей похилого та старечого віку в загальній чисельності населення. Остеоартроз (ОА) є поширеною формою суглобової патології, він уражає 10-20 \% населення. Захворювання корелює з віком, частіше розвивається після 30-35 років. Ознаки ОА виявляють у $90 \%$ людей старше 70 років. ОА викликає стійкий 6ольовий синдром, порушення функції суглобів, зниження якості життя і може бути причиною інвалідизації у пацієнтів похилого віку [4].

У клінічний практиці при первинному гонартрозі (ПГА) часто доводиться стикатися з хронічним больовим синдромом, обумовленим позасуглобовими патогенетичними механізмами. Наростаючі позасуглобові зміни при ПГА являють собою реалізацію складного комплексу компенсаторно-пристосувальних реакцій. При цьому найчастішим пусковим механізмом болю стають анатомо-функціональні та біомеханічні невідповідності. Особливо чутливими до будь-яких внутрішніх та зовнішніх негативних впливів на суглоб $\epsilon$ м'язи, які безпосередньо його оточують $[6,8,9$, 12]. Тому досить часто ОА супроводжується м'язовою дисфункцією, що призводить до обме- ження рухливості суглоба та виникнення больового синдрому [5].

М'язи мають вирішальне значення для підтримки рухливості, стабільності та функції суглобів $[3,7]$, вони допомагають у поглинанні ударів та передачі зусилля через суглоби і забезпечують динамічну стійкість до нормального і пошкодженого суглоба $[7,10]$. Відомо, що ноцицептивні імпульси із зони ураженого суглоба гальмують діяльність м'язів та їх спінальних центрів [3]. Таке захисне гальмування не тільки позначається на стані м'язів, які безпосередньо беруть участь в роботі суглоба, але може впливати і на діяльність інших м'язів. За даними багатьох дослідників [7, 13], розлади пропріоцептивної імпульсації приводять до зниження тонусу параартикулярних м'язів і, як наслідок цього, - до посилення механічного навантаження на суглоб.

Крім того, патологія колінних суглобів спричиняє зміни функціонування всього опорно-рухового апарату, в першу чергу хребта. Хребет і нижні кінцівки $\epsilon$ елементами загальної системи опори тіла та його активних рухів, які мають взаємний структурно-функціональний вплив, загальні центри управління. При патології одного суглоба наявність больового синдрому змушує щадити кін- 
Огляди літератури, оригінальні дослідження, погляд на проблему, ювілеї

цівку, що супроводжується гіпотрофією м'язів і перерозподілом їх тонусу. В м'язах хворої кінцівки з'являються ділянки ущільнення, склерозування, знижується їх еластичність. Час скорочення і, особливо, розслаблення подовжується. Такий стан м'язів позначається на трофіці всіх тканин суглобів. Водночас, асиметричність алгічного синдрому призводить до формування анталгічної пози і патологічної ходи, посилюються порушення конгруентності суглобових поверхонь, збільшуються їх перенавантаження [3, 5]. Відбуваються зміни і в м'язах, які оточують хребет [2].

Все це вказує на необхідність підбору для хворих на ОА реабілітаційних комплексних програм, які дозволять відновити статико-динамічні властивості кістково-м'язової системи і матимуть одночасно протизапальну, знеболювальну та антиспазмолітичну дію, поліпшать гемодинаміку та мікроциркуляцію. Медикаментозна терапія ОА істотно обмежена і включає хондропротектори, нестероїдні протизапальні, спазмолітичні препарати. Відчутно ширші можливості фізичних чинників. Їх застосування не ускладнюється побічною дією, яка властива для медикаментозної терапії $[4,15]$.

Однак в останні роки кількість оперативних втручань із заміни уражених остеоартритом суглобів значно збільшилася, що може свідчити про недостатню ефективність консервативного лікування на ранніх стадіях захворювання [14] і закономірне збільшення кількості запущених випадків. Близько 20 \% хірургічних втручань не дають задовільних результатів [11]. Тому пошук ефективних консервативних методів реабілітації у хворих з гонартрозом, які дозволять сповільнити прогресування захворювання, поліпшити функціональні показники і підвищити якість життя пацієнтів, як і раніше, залишається актуальним.

Мета роботи - патогенетичне обґрунтування застосування реабілітаційного комплексу із включенням методик для корекції патобіомеханічних порушень у хворих на первинний гонартроз (ПГА) в похилому віці на амбулаторному етапі реабілітації.

Матеріал і методи дослідження. Клінічні спостереження проведені у 42 пацієнтів з ПГА, які перебували на амбулаторному етапі реабілітації. Серед досліджуваних хворих було 32 жінки та 10 чоловіків у віці 61-77 років (середній вік $(65,1 \pm$ $0,3)$ років).

Діагноз ОА встановлювали відповідно до клініко-рентгенологічних критеріїв Американської колегії ревматологів (R. Altman, 1991). Тривалість захворювання з моменту виникнення перших симптомів коливалася від 5 до 16 років (у середньому $(9,2 \pm 0,4)$ років).

Критеріями включення пацієнтів у дослідження були: рівень болю за шкалою ВАШ не більше 60 мм, клініко-рентгенологічна стадія ОА не вище II, функціональна недостатність суглобів I-II ст., наявність неспецифічного болю в поперековому відділі хребта з рівнем болю за ВАШ не більше 50 мм.

У дослідження не ввійшли пацієнти з різко вираженими порушеннями функції суглоба (нездатність до самостійного пересування); зі суглобовим синдромом на ґрунті дифузних захворювань сполучної тканини; пацієнти, яким проводилася системна і внутрішньосуглобова (у досліджуваний суглоб) терапія кортикостероїдами впродовж останніх 6 місяців, із спінальною патологією, з радикулярним больовим синдромом, а також пацієнти із супутньою патологією, яка загалом протипоказана проведенню реабілітації.

Методом рандомізації пацієнти були поділені на дві групи (І група - n=18; II група - n=24). Відчутної різниці за основними вихідними клініко-функціональними показниками між групами не спостерігалося. Всі пацієнти отримували реабілітаційний комплекс, який включав: інтерференцтерапію на колінні суглоби № 8, аплікації гальваноболота температурою $28-30{ }^{\circ} \mathrm{C}$ № 8, вправи постізометричної реалаксації № 8, об'ємний пневмопресинг (ОПП) на колінні суглоби (методика здійснювалась за допомогою апарату БИО-1, на нижній кінцівці щільно закріплювали пневмоманжету, режим переміщення пневмохвилі двосторонній, тривалість 12 хвилин, курс лікування 8 сеансів). Схема лікування між групами відрізнялася наявністю в II групі додаткового впливу ОПП на м'язи поперекового відділу хребта (пацієнт в горизонтальному положенні на спині розміщувався на пневматичному матрасі, режим переміщення пневмохвилі двосторонній, тривалість 12 хвилин, курс лікування 8 сеансів).

Для оцінки ступеня вираженості болю в суглобах нами була використана візуальна аналогова шкала (ВАШ), а для характеристики функціональних порушень - анкета для визначення альгофункціонального індексу Lequesne та опитувальник Western Ontario and McMaster Universities (WOMAC) [2]. Для визначення функціональної сили м'язів нижньої кінцівки використано тест Ловетта. Ми відображали силу м'язів в процентах: 0=0 \%, 1=10\%, 2=25 \%, 3=50 \%, 4=75 \%, 5=100 \%. Усім пацієнтам, включеним в дослідження, проводилися клініконеврологічне дослідження, візуальна та мануальна діагностика [1], мануальне м'язове тестування (MMT).

Критеріями оцінки ефективності реабілітації були зменшення вертебрального та суглобового больового синдромів (за візуальною аналоговою шкалою (ВАШ)), зменшення ступеня неврологічних та ортопедичних порушень (за даними стан- 
Огляди літератури, оригінальні дослідження, погляд на проблему, ювілеї

дартних схем вертеброневрологічного обстеження, проби Шобера, індексу Лекена для гонартрозу), регрес порушень тонусу та сили м'язів спини та нижніх кінцівок (ММТ, тест Ловетта), зменшення функціональних порушень - (опитувальник WOMAC).

Статистичну обробку отриманих результатів проводили за допомогою пакета статистичних програм «Statistica 10.0» (StatSoft, Inc., USA). Для визначення достовірності відмінностей у зміні певного показника використовували критерії Уілкоксона, Краскела-Уоліса. Вірогідними вважали відмінності при ступені ймовірності безпомилкового прогнозу (p) $95 \%(p<0,05)$.

Результати й обговорення. Основними скаргами пацієнтів були біль у колінних суглобах і в поперековому відділі хребта, який посилювався при ходьбі, скутість у м'язах попереку, обмеження рухів у поперековому відділ хребта та колінних суглобах.

Аналіз особливостей больового синдрому, статичних і динамічних чинників, які підсилюють і зменшують вираженість болю, показав існування загальних і різних біомеханічних і м'язово-тонічних порушень при різній локалізації болю. У всіх пацієнтів спостерігався дисбаланс м'язів нижніх кінцівок, це призводило до компенсаторної перебудови осьового скелета та перевантаження м'язів поперекового відділу хребта.

На підставі результатів візуальної діагностики статичної складової рухового стереотипу встановлено, що 100 \% пацієнтів мають рефлекторний постуральний дисбаланс м'язів в ділянці попереково-крижового відділу хребта.

Аналіз патобіомеханічних порушень, виявлених при візуальній діагностиці, показав, що всі пацієнти з ПГА мали неоптимальний руховий стереотип. У 87 \% пацієнтів виявлена асиметрія кінцівок, у інших пацієнтів довжина кінцівок збережена, але спостерігався дисбаланс м'язів тазової ділянки. В обох випадках це призводило до компенсаторної перебудови осьового скелета, перевантаження м'язів поперекового відділу хребта або м'язів які оточують колінний суглоб.

Оцінку ефективності застосування реабілітаційного комплексу з включенням методу ОПП локально та комбінованого впливу ОПП на суглоби та м'язи хребта проводили на основі комплексного зіставлення даних, отриманих в результаті клінічних та функціональних методів дослідження як до, так і після амбулаторного етапу реабілітації.

За клінічними ознаками у проведеному дослідженні відхилень від норми артеріального тиску та частоти серцевих скорочень не відмічалось, не спостерігались патологічні зміни на ЕКГ, також не виявлено змін зі сторони інших систем протягом усього курсу амбулаторного етапу реабілітації.

Як видно з даних таблиці 1, у двох групах обстежених пацієнтів після отримання реабілітаційного комплексу із застосуванням ОПП спостерігалося зменшення ступеня вираження больового синдрому в колінних суглобах за даними ВАШ, індексу Лекена та WOMAC $(p<0,05)$, однак в II групі при застосуванні комбінованого впливу ОПП відмічалась достовірна позитивна динаміка показників, які свідчили про зниження ступеня вираженості вертебрального синдрому $(p<0,05)$. Послідовний надув відсіків пневмоманжети за типом "хвилі, що біжить» викликає покращення стану м'язів хребта (біомеханічну корекцію), активацію сегментарно-рефлекторних зон та підвищення функціональної активності пацієнтів. Порівнюючи ефективність лікування в досліджуваних групах можна констатувати більш виражений клінічний ефект комбінованого впливу ОПП $(p<0,05)$.

Таблиця 1. Динаміка суглобового та вертебрального синдромів у обстежених пацієнтів в процесі лікування

\begin{tabular}{|c|c|c|c|c|}
\hline \multirow{2}{*}{ Показник } & \multicolumn{2}{|c|}{$\begin{array}{l}1 \text { група } \\
(n=18) \\
\end{array}$} & \multicolumn{2}{|c|}{$\begin{array}{l}2 \text { група } \\
(n=24) \\
\end{array}$} \\
\hline & $\begin{array}{c}\text { до } \\
\text { лікування }\end{array}$ & $\begin{array}{c}\text { після } \\
\text { лікування }\end{array}$ & $\begin{array}{c}\text { до } \\
\text { лікування }\end{array}$ & $\begin{array}{c}\text { після } \\
\text { лікування }\end{array}$ \\
\hline Біль в суглобах за ВАШ у спокої, мм & $51,13 \pm 0,76$ & $36,09 \pm 0,90^{a}$ & $52,88 \pm 0,77$ & $26,79 \pm 0,81 \mathrm{ab}$ \\
\hline Біль в суглобах за ВАШ при русі, мм & $55,16 \pm 0,71$ & $34,62 \pm 0,62^{a}$ & $54,41 \pm 0,76$ & $26,53 \pm 0,68$ ab \\
\hline Біль в хребті за ВАШ в спокої, мм & $38,17 \pm 0,80$ & $36,24 \pm 1,71$ & $40,22 \pm 0,64$ & $24,15 \pm 0,32^{a b}$ \\
\hline Біль в хребті за ВАШ при русі, мм & $46,22 \pm 0,84$ & $42,17 \pm 0,14$ & $47,21 \pm 0,68$ & $32,13 \pm 0,15^{a b}$ \\
\hline Сумарний індекс WOMAC, бали & $58,11 \pm 0,94$ & $38,30 \pm 0,65$ a & $57,59 \pm 0,66$ & $34,71 \pm 0,43$ ab \\
\hline Індекс Лекена, бали & $7,02 \pm 0,11$ & $4,97 \pm 0,18^{a}$ & $6,91 \pm 0,11$ & $4,72 \pm 0,19^{a}$ \\
\hline Проба Шобера, см & $3,47 \pm 0,13$ & $4,12 \pm 0,16$ & $3,59 \pm 0,14$ & $5,18 \pm 0,12^{a b}$ \\
\hline Тест Ловетта & $42,32 \pm 2,30$ & $61,22 \pm 2,05$ & $44,41 \pm 2,36$ & $66,62 \pm 2,12^{a}$ \\
\hline Об'єм рухів у суглобах, град. & $108,18 \pm 1,66$ & $128,26 \pm 1,78^{a}$ & $106,32 \pm 1,76$ & $148,29 \pm 1,86^{\mathrm{ab}}$ \\
\hline
\end{tabular}

Примітки: $1 .{ }^{\text {a } ~-~ р і з н и ц я ~ п о к а з н и к а ~ с т а т и с т и ч н о ~ з н а ч у щ а ~}(p<0,05)$ до і після лікування в межах групи;

2. ${ }^{\mathrm{b}}$ - різниця показника статистично значуща $(p<0,05)$ після лікування між групами. 
Висновки. 1. Для адекватної діагностики та проведення правильної реабілітаційної тактики у хворих на ПГА та з неспецифічними болями в поперековому відділі хребта необхідні візуальна діагностика і мануальне тестування, що дозволяють виявляти патобіомеханічні рухові порушення.

2. Багатофакторність механізму формування суглобного болю обумовлює необхідність визначення взаємозв'язку больового синдрому з причиною його появи. Безпосередній вплив на домінантне больове вогнище (симптоматична терапія) не завжди призводить до його полегшення, тому реалізація лікувального впливу з урахуванням етіопатогенетичного і симптоматичного підходів повинна здійснюватися не тільки на рівні ураженого суглоба і навколосуглобових структур, а й на рівні всієї нижньої кінцівки та рефлекторно-сегментарних зон.

3. Включення ОПП у програму лікування гонартрозу з урахуванням етіопатогенетичних i симптоматичних особливостей розвитку захворювання дозволить підвищити ефективність реабілітації цієї групи хворих за допомогою максимально ефективного впливу на всі структурнофункціональні рівні.

Перспективи подальших досліджень. О6грунтування та дослідження реабілітаційних заходів для корекції неоптимального рухового стереотипу.

\section{ЛІТЕРАТУРА}

1. Васильева Л. Ф. Клиника и визуальная диагностика укороченных мышц : учебное пособие / Л. Ф. Васильева. - М. : Медицина, 2003. - 169 с.

2. Комплексная физиотерапия больных дорсопатиями с сопутствующим остеоартрозом / А. А. Зайцев, Н. Ф. Мирютова, Е. В. Михайлова, А. В. Попова // Вопросы курортологии, физиотерапии и лечебной физической культуры. - 2011. - № 2. - С. 21-24.

3. Особенности функционирования мышц нижних конечностей и их спинальных центров при гонартрозах / А. М. Еремеев, А. А. Трофимова, И. И. Шайхутдинов [и др.] // Практическая медицина. -2011. - № 7 (55). - С. 64-68.

4. Коваленко В. Н. Остеоартроз : практическое руководство / В. Н. Коваленко, О. П. Борткевич. - К. : Морион, 2010. - 601 с.

5. Королева С. В. Роль миофасциального синдрома в дестабилизации коленного сустава при остеоартрозе / С. В. Королева, С. Е. Львов // Современные проблемы науки и образования. - 2007. - № 2. - С. 50-54.

6. Шостак Н. А. Клинические варианты остеоартроза - подходы к терапии / Н. А. Шостак, Н. Г. Правдюк, А. А. Клименко // Русский медицинский журнал. -2011. T. 19, № 2. - С. 93-97.

7. Role of muscle in the genesis and management of knee osteoarthritis / K. L. Bennell, M. A. Hunt, T. V. Wrigley [et al.] // Rheum. Dis. Clin. North Am. - 2008. - No. 34 (3). - P. 731-754.

8. Gallagher R. M. Chronic pain: sources of late life pain and risk factor for disability / R. M. Gallagher // Geriatrics. 2005. - Vol. 55. - P. 40-47.

\section{REFERENCES}

1. Vasilyeva, L.F. (2003). Klinika i vizualnaya diagnostika ukorochennykh myshts [Clinic and visual diagnosis of shortened muscles]. Moscow: Meditsina [in Russian].

2. Zaytsev, A.A., Miryutova, N.F., Mikhaylova, E.V., \& Popova, A.V. (2011). Kompleksnaya fizioterapiya bolnykh dorsopatiyami s soputstvuyushchim osteoartrozom [Comprehensive physiotherapy in patients with dorsopathies with concomitant osteoarthrosis]. Voprosy kurortologii, fizioterapii i lechebnoy fizicheskoy kultury - Questions of Balneology, Physiotherapy and Medical Physical Culture, 2, 21-24 [in Russian].

9. Hip muscle weakness in individuals with medial knee osteoarthritis / R. S. Hinman, M. A. Hunt, M. W. Creaby [et al.] // Arthritis Care Res (Hoboken). - 2010. - Vol. 62. No. 8. - P. 1190-1193.

10. Elboim-Gabyzon M. Quadriceps femoris muscle fatigue in patients with knee osteoarthritis / M. Elboim-Gabyzon, N. Rozen, Y. Laufer // Clin. Interv. Aging. - 2013. - No. 8. P. 1071-1077.

11. National Clinical Guideline Centre. Oste-oarthritis. Care and management in adults. Lon-don: National Institute for Health and Care Excel-lence, 2014. - 556 p.

12. Knee extensor muscle weakness is a risk factor for development of knee osteoarthritis. A systematic review and meta-analysis / B. E. Oiestad, C. B. Juhl, I. Eitzen, J. B. Thorlund // Osteoarthritis Cartilage. - 2014. - Vol. 1. P. $1305-1308$.

13. Muscle weakness, afferent sensory dysfunction and exercise in knee osteoarthritis / E. M. Roos, W. Herzog, J. A. Block, K. L. Bennell // Nat. Rev. Rheumatol. - 2011. No. 7 (1). - P. 57-63.

14. Sofat N. What makes osteoarthritis painful? The evidence for local and central pain processing / N. Sofat, V. Ejindu, P. Kiely // Rheumatology (Oxford). - 2011. Vol. 50. - P. 2157-2165.

15. Stemberger R. Osteoarthritis: physical medicine and rehabilitation-nonpharmacological management / R. Stemberger, K. Kerschan-Schindl // Wien Med Wochenschr. - 2013. - No. 163 (9-10). - P. 228-235.

3. Eremeyev, A.M., Trofimova, A.A., Shaykhutdinov, I.I., Zagidullin M.V., \& Valeev, Y.A. (2011). Osobennosti funktsionirovaniya myshts nizhnikh konechnostey i ikh spinalnykh tsentrov pri gonartrozakh [Features of the functioning of the muscles of the lower extremities and their spinal centers in gonarthrosis]. Prakticheskaya meditsynaPractical Medicine, 7 (55), 64-68 [in Russian].

4. Kovalenko, V.N., \& Bortkevich O.P. (2010). Osteoartroz: prakticheskoye rukovodstvo [Osteoarthritis: a practical guide]. Kiev: Morion [in Russian]. 
Огляди літератури, оригінальні дослідження, погляд на проблему, ювілеї

5. Koroleva, S.V., \& Lvov, S.E. (2007). Rol miofastsialnogo sindroma $v$ destabilizatsii kolennogo sustava pri osteoartroze [The role of myofascial syndrome in the destabilization of the knee with osteoarthritis]. Sovremennyye problemy nauki i obrazovaniya - Modern Problems of Science and Education, 2, 50-54 [in Russian].

6. Shostak, N.A., Pravdiuk, N.H., \& Klymenko, A.A. (2011). Klinicheskiye varianty osteoartroza - podkhody k terapii [Clinical variants of osteoarthritis - approaches to therapy]. Russkiy meditsynskiy zhurnal - Russian Medical Journal, 19 (2), 93-97 [in Russian].

7. Bennell, K.L., Hunt, M.A., Wrigley, T.V., Lim, B.W., \& Hinman, R.S. (2008) Role of muscle in the genesis and management of knee osteoarthritis. Rheum. Dis. Clin. North Am., 34 (3), 731-754.

8. Gallagher, R.M. (2005). Chronic pain: sources of late life pain and risk factor for disability. Geriatrics, 55, 40-47.

9. Hinman, R.S., Hunt, M.A., \& Creaby, M.W. (2010). Hip muscle weakness in individuals with medial knee osteoarthritis. Arthritis Care Res. (Hoboken), 62 (8), 1190-1193.
10. Elboim-Gabyzon, M., Rozen, N., Laufer Y. (2013). Quadriceps femoris muscle fatigue in patients with knee osteoarthritis. Clin. Interv. Aging, 8, 1071-1077.

11. National Clinical Guideline Centre. (2014). Osteoarthritis. Care and management in adults. London: National Institute for Health and Care Excellence.

12. Oiestad, B.E., Juhl, C.B., Eitzen, I., \& Thorlund, J.B. (2014). Knee extensor muscle weakness is a risk factor for development of knee osteoarthritis. A systematic review and meta-analysis. Osteoarthritis Cartilage, 1, 1305-1308.

13. Roos, E.M., Herzog, W., Block, J.A., \& Bennell, K.L. (2011). Muscle weakness, afferent sensory dysfunction and exercise in knee osteoarthritis. Nat. Rev. Rheumatol., 7(1), 57-63.

14. Sofat, N., Ejindu, V., \& Kiely, H. (2011). What makes osteoarthritis painful? The evidence for local and central pain processing. Rheumatology (Oxford), 50, 2157-2165.

15. Stemberger, R., \& Kerschan-Schindl, K. (2013). Osteoarthritis: physical medicine and rehabilitation-nonpharmacological management. Wien Med. Wochenschr., 163(910), 228-235.

\title{
ПАТОБИОМЕХАНИЧЕСКИЕ НАРУШЕНИЯ И МЕТОДЫ КОРРЕКЦИИ ПРИ ПЕРВИЧНОМ ГОНАРТРОЗЕ У ПАЦИЕНТОВ ПОЖИЛОГО ВОЗРАСТА
}

\author{
๑Т. Г. Бакалюк, И. Р. Мисула, Г. О. Стельмах, Ю. В. Завиднюк,
} Х. Я. Максив, Н. Б. Жеворонко

\author{
Гвуз «Тернопольский государственный медицинский университет имени И. Я. Горбачевского \\ МОЗ Украины»
}

PЕЗЮМЕ. У лиц пожилого и старческого возраста проблема остеоартроза (ОА) приобретает особое значение в связи с сопутствующими заболеваниями и инволютивными изменениями в организме. Патология коленных суставов вызывает изменения функционирования всего опорно-двигательного аппарата, в первую очередь позвоночника. Подбор для больных ОА реабилитационных комплексных программ, которые позволят восстановить статико-динамические свойства костно-мышечной системы и будут иметь одновременно противовоспалительное, обезболивающее и антиспазмолитическое действие, остается актуальной задачей. Все это является побудительным моментом поиска путей коррекции патобиомеханических нарушений при проведении реабилитации больных ОА коленных суставов в пожилом возрасте.

Цель работы - патогенетическое обоснование применения реабилитационного комплекса с включением методик для коррекции патобиомеханических нарушений у больных первичным гонартрозом в пожилом возрасте на амбулаторном этапе реабилитации.

Материал и методы. В исследовании участвовали 42 больных первичным гонартрозом с неспецифическим болевым синдромом в поясничном отделе позвоночника, которые находились на амбулаторном этапе реабилитации. Средний возраст составил $(65,13 \pm 0,31)$ г., продолжительность заболевания $(9,24 \pm 0,42)$ р. Пациенты были разделены на 2 группы, реабилитационные комплексы различались методиками применения объемного пневмопрессинга.

Результаты. Установлено достоверное $(p<0,05)$ уменьшение болевого синдрома как в суставе, так и в поясничном отделе позвоночника, улучшение функциональной активности, тонуса мышц и физической работоспособности при применении предложенного реабилитационного комплекса с коррекцией патобиомеханических нарушений.

Выводы. На основании полученных результатов предложен дифференцированный подход к назначению реабилитационных мероприятий у больных первичным гонартрозом в зависимости от патобиомеханических нарушений. С помощью комбинированной методики применения объемного пневмопрессинга локально на коленные суставы и на мышцы спины устраняются изменения в мышечном аппарате коленных суставов и позвоночника.

КЛЮЧЕВЫЕ СЛОВА: мышечная дисфункция; объемный пневмопрессинг; остеоартроз; патобиомеханические нарушения; реабилитация. 


\section{PATHOBIOMECHANICAL DISORDERS AND METHODS OF CORRECTION IN PRIMARY GONARTHRITIS IN THE ELDERLY}

\section{T. G. Bakalyuk, I. R. Misula, H. O. Stelmakh, Yu. V. Zawidniuk, H. Ya. Maxiv, N. B. Zhevoronko I. Horbachevsky Ternopil State Medical University}

SUMMARY. In the elderly, the problem of osteoarthritis (OA) becomes very important in connection with concomitant diseases and involutive changes in the body. Pathology of knee joints causes changes in the functioning of the entire musculoskeletal system, primarily the spine. Selection for patients with OA rehabilitation complex programs that will restore the static-dynamic properties of the bone and muscular system, and will have both anti-inflammatory, analgesic and anti-spasmolytic action remains an urgent task. All this is a motive for finding ways to correct pathobiomechanical disorders during rehabilitation of patients with OA knee joints in the elderly.

The aim of the study - pathogenetic substantiation of the application of the rehabilitation complex with the inclusion of techniques for correction of pathobiomechanical disorders in patients with primary gonarthritis in the elderly at the outpatient stage of rehabilitation.

Material and Methods. The study involved 42 patients with primary gonarthrosis with non-specific pain syndrome in the lumbar spine, who were in the outpatient stage of rehabilitation. The average age was $(65.13 \pm 0.31)$ years, the duration of the disease $(9.24 \pm 0.42)$ years. Patients were divided into 2 groups, rehabilitation complexes differed in methods of using volumetric pneumopressing.

Results and Discussion. Reliable $(p<0.05)$ reduction of pain syndrome both in the joint and in the lumbar spine, improvement of functional activity, tone of muscles and physical capacity when using the proposed rehabilitation complex with correction of pathobiomechanical disorders was established.

Conclusions. On the basis of the obtained results, a differentiated approach is proposed for the appointment of rehabilitation measures in patients with primary gonarthrosis depending on pathobiomechanical disorders. With the help of the combined method of using volumetric pneumopressing locally on the knee joints and on the back muscles are eliminated changes in the muscular system of the knee joints and the spine.

KEY WORDS: muscular dysfunction; volumetric pneumopressing; osteoarthritis; pathobiomechanical disorders; rehabilitation.

Отримано 02.11.2018 